\title{
Questes
}

vestes Revue pluridisciplinaire d'études médiévales

6 | 2004

La nuit

\section{La nuit religieuse}

\section{Audrey Sulpice}

\section{(2) OpenEdition}

\section{Journals}

\section{Édition électronique}

URL : http://journals.openedition.org/questes/1913

DOI : 10.4000/questes.1913

ISSN : 2109-9472

\section{Éditeur}

Les Amis de Questes

\section{Édition imprimée}

Date de publication : 15 janvier 2004

Pagination : 20-26

ISSN : 2102-7188

\section{Référence électronique}

Audrey Sulpice, «La nuit religieuse », Questes [En ligne], 6 | 2004, mis en ligne le 01 janvier 2014 consulté le 15 septembre 2020. URL : http://journals.openedition.org/questes/1913

Ce document a été généré automatiquement le 15 septembre 2020.

(C) Association des amis de «Questes » 


\section{La nuit religieuse}

\section{Audrey Sulpice}

\section{NOTE DE L'ÉDITEUR}

Cet article n'a pas encore fait l'objet d'une autorisation de publication.

\section{INDEX}

Mots-clés : nuit, mort, épreuve, religieux, adversaire, vol, obscurité, malédiction, péché, luxure, rêve, sommeil, prière

Keywords : night, death, trial, religious, adversary, darkness, robbery, lechery, sin, fear, sleep, dream, praying 